\title{
A GRÉCIA PENSANDO A SI MESMA: O SIGNIFICADO JURÍDICO-POLÍTICO DA COMÉDIA DE ARISTÓFANES
}

\author{
Cesar Antonio Serbena*
}

RESUMO: O objetivo do presente trabalho é analisar como o berço da democracia, a cidade de Atenas na Grécia Clássica, refletia sobre sua própria invenção, através da comédia "As Vespas” de Aristófanes. A peça é um veículo privilegiado de análise histórica, pois o cotidiano da democracia ateniense é mencionado e mantém-se como pano de fundo da narrativa. Porém, a característica mais importante consiste na análise da crítica de Aristófanes ao conjunto das instituições democráticas atenienses e o que elas representavam para os próprios cidadãos atenienses. Em um primeiro momento, descrevemos o contexto da peça, ou seja, as características das principais instituições jurídicas da Atenas clássica e sua dinâmica de funcionamento. A segunda parte consiste na transcrição e análise de trechos importantes da peça.

INTRODUÇÃO - O SISTEMA JUDICIAL ATENIENSE

\section{Os Magistrados}

A magistratura era um cargo de duração curta, de um ano, acessível a qualquer cidadão ateniense, e em geral, não era permitido o exercício por vários anos seguidos e mais de uma magistratura ao

* Doutor em Direito, professor dos cursos de Graduação e da Pós-Graduação da Faculdade de Direito da UFPR, e da disciplina de História do Direito e do Pensamento Jurídico na graduação da mesma faculdade. mesmo tempo, com exceção para o cargo de estratego. Péricles ocupou este cargo durante quinze vezes.

As magistraturas mais altas, como o comando do exército, não eram remuneradas, ao contrário dos postos baixos, bastante procurados pelo cidadão médio. As magistraturas funcionavam em regime colegiado, sendo cada grêmio independente do outro. A remuneração das magistraturas, instituída por Péricles, denominava-se mistoforia, e compreendia também o pagamento pela presença nas Assembléias. Esta foi a forma encontrada por Péricles para 
promover a participação do cidadão médio nos cargos políticos e assegurar o acesso deste aos postos, pois na sociedade grega somente a classe superior poderia dispor de tempo livre para ocupar-se dos negócios públicos. A mistoforia desagradava a aristocracia e a filósofos como Aristóteles, que viam nesta medida um desvio de finalidade da atividade política. O povo participaria apenas objetivando a remuneração do cargo e não o bem da cidade.

A mais alta magistratura era, historicamente, o Areópago ou o colégio dos arcontes. Os seus membros eram escolhidos por sorteio entre os candidatos apontados pelas tribos. Apesar do sorteio, na época de Sólon, geralmente apenas cidadãos das classes mais altas, como os pentacosiomedinos, tornavamse magistrados do Areópago. Com as Guerras Médicas permitiu-se o acesso à magistratura aos cavaleiros, e com a Guerra do Peloponeso, aos zeugítai. A possibilidade de exercício da magistratura por essas classes representou um prêmio pelo esforço e vitória de Atenas nas batalhas contras os persas e contra os beócios e espartanos em 457/6 aC. O sistema definitivo de escolha dos magistrados, cuja concepção foi o de acabar com as fraudes nas eleições nos demos, foi denominado de nomeação "pela fava". Consistia em um duplo sorteio: os candidatos seriam sorteados, em primeiro lugar, na tribo, até o número de dez; em segundo lugar, entre os sorteados pelas tribos, seria feito o sorteio final para a magistratura.

Antes de tomar posse no cargo de magistrado, o candidato eleito ou sorteado passava por um exame de conduta pregrassa denominado docimasia. Como relatado por Aristóteles, o novo magistrado deveria responder a perguntas sobre sua origem como "Quem é teu pai? A que dêmos pertence? Quem é o pai de teu pai? Quem é tua mãe? Quem é o pai de tua mãe, e de que dêmos?". Em seguida, deveria responder a questões sobre sua participação em um culto de Zeus e de Apolo, se sua família possui jazigos e onde se encontram, se trata bem os seus pais, se paga os seus impostos e se cumpriu suas obrigações militares. Após a resposta às perguntas, o candidato deve apresentar testemunham que abonem o que foi respondido.

Antes do magistrado ser empossado, este deveria prestar um juramento. Dependendo da magistratura, havia diferenças entre as fórmulas do juramento, mas todas continham o compromisso de que o empossado obedeceria às leis e não se deixaria corromper. Os arcontes juravam oferecer uma estátua de ouro do tamanho respectivo de cada um, se aceitassem presentes.

A Assembléia exercia um controle permanente sobre a atividade dos magistrados. $\mathrm{Na}$ Assembléia principal de cada pritania, ela procedia à epikheirotonía, a submissão, à votação, pela contagem dos braços erguidos, da gestão dos magistrados, que poderiam ser reconduzidos ao cargo, caso se considerasse bom o cumprimento de suas funções, ou poderiam ser exonerados e julgados. Isso significava que nove vezes por ano o magistrado era submetido ao exame da Assembléia. Havia uma classe específica de funcionários treinados no exame das contas, os logistas (logistaí), uma classe de peritos contábeis. Cada magistrado era pessoalmente responsável com seus bens e solidariamente com o seu colégio pelos erros ou crimes cometidos durante sua gestão. Antes de 
prestarem contas de sua gestão, não podiam deixar o país, subtrair o seu patrimônio ou mudar de família. A responsabilidade do magistrado era dupla, primeiramente financeira e secundariamente moral e política.

\section{A Justiça em Atenas}

Em Atenas havia duas espécies de ações judiciais: as ações privadas (díkai) e as ações públicas (graphaî). Nas ações privadas, as duas partes depositam as custas judiciárias, as pritanias. $\mathrm{O}$ autor pode renunciar à ação; se vence, pode obter, além do objeto do litígio, uma indenização, mas ele mesmo deve executar a sentença. Nas ações públicas, somente o autor deve depositar as custas judiciárias (parástasis); se renuncia, ou se não consegue pelo menos um quinto dos votos, deve pagar multa de mil dracmas. Ao condenado podem aplicar-se penas corporais, infamantes ou pecuniárias, e estas revertem em benefício da cidade. A luta judicial é apenas entre as partes. O magistrado apenas organiza o debate, recolhe as declarações formuladas e as provas fornecidas pelos adversários.

Os processos poderiam ser abertos diante da Assembléia ou do Conselho através da eisaggelía e da probolê. A primeira consistia numa ação, que poderia ser iniciada por qualquer cidadão, contra qualquer pessoa que tivesse violado a santidade das festas sagradas ou que tivesse enganado o povo. A segunda ação era mais séria e era intentada contra o autor de um crime contra a segurança do Estado. $\mathrm{O}$ acusado era entregue, de pés e mãos atados, aos juízes.

Em caso de flagrante delito, ou de delito notório, ou quando o acusado pode facilmente fugir, os cidadãos dispõem da apagôgê (é lícito apreender fisicamente o malfeitor e arrastá-lo para diante do juiz), da ephêgêsis (condução do magistrado onde se encontra o delinqüente, para que este seja preso), e da éndeixis (denúncia do delinqüente ao magistrado competente).

\section{Os Tribunais}

O mais alto tribunal na hierarquia da magistratura ateniense era o mais antigo deles, o Areópago. A sua competência era julgar os crimes de homicídio premeditado, tentativa de homicídio que resultasse em lesões corporais, de incêndio de uma casa habitada e de envenenamento. As sentenças poderiam ser a morte, em caso de assassinato, e o exílio e o confisco, em caso de lesões corporais.

De hierarquia inferior ao Areópago, estão os três tribunais compostos por 51 efetas, de acordo com a legislação de Drácon:

- Palládion: competente em matéria de homicídio involuntário e de instigação ao homicídio, se a vítima é um cidadão, e, em matéria de assassinato, tanto voluntário quanto involuntário, desde que se trate de um meteco, de um estrangeiro ou de um escravo. Pronuncia a sentença de exílio por tempo determinado, sem confisco; o condenado somente pode regressar à Ática com autorização dos parentes do morto.

- Delphínion: competente, se o rei, incumbido da instrução do processo, decidir que o homicídio é desculpável ou legítimo, que é o caso quando a vítima foi morta nas competições atléticas, lutando, ou na guerra, por equívoco, ou também em flagrante delito de relações ilícitas com a esposa, a mãe, a irmã, a filha ou a concubina livre do assassino. 
- Phreattús: são julgados, na borda do oceano, os que, banidos temporariamente por homicídio involuntário, cometeram novo assassinato com premeditação. Como ainda não se purificaram da primeira mancha, e como lhes é proibido o ingresso em terra ática, os acusados apresentam sua defesa do alto de uma barca, diante de juízes sentados à beira do mar. Se forem absolvidos, voltam à terra estrangeira, e se forem culpados, sofrem a pena de morte.

Há ainda um quinto tribunal, de origem bastante arcaica, constituído pelo rei e pelos reis de tribos. Ele condena o assassino desconhecido e julga o animal ou objeto de pedra, ferro ou madeira, que causou a morte da vítima, e, em seguida, purifica o terreno, mandando transportar o animal ou jogar o objeto além das fronteiras.

Em 453/2 aC, restabeleceu-se os juízes de dêmos, criados por Pisístrato, aos quais cabia julgar em primeira e última instância as causas não maiores que 10 dracmas. Esses juízes eram itinerantes e atuavam dentro de sua tritús, ou seja, no litoral, na cidade ou no interior.

As causas superiores a dez dracmas cabiam aos árbitros públicos, que eram denominados diaitêtai, sendo que esse cargo cabia obrigatoriamente aos cidadãos com 60 anos de idade por um ano. Repartiam-se os diatêtai em dez secções, uma por cada tribo.

Os tribunais populares cabiam aos heliastas. Todo ateniense poderia conseguir o cargo de heliasta, desde que cumprisse os requisitos: possuir 30 anos, estar em pleno gozo dos direitos cívicos, e nada dever ao tesouro público. Segundo Aristóteles, fixou-se no século $\mathrm{V}$ aC em 6 mil o número de heliastas, sorteados pelo arcontado entre os cidadãos.
Cada tribo fornecia 600 juízes. Os juízes eram divididos entre os tribunais e desse modo sabiam as causas que iriam jular durante o ano. Antes de $425 \mathrm{aC}$, em cada sessão os heliastas eram remunerados por dois óbolos; a partir desse ano, por três óbolos, o trióbolo. Esta foi a maneira encontrada para que o povo cumprisse deveres legais para com o regime democrático.

A citação era feita pelo próprio queixoso, acompanhado por duas testemunhas, cujo depoimento, em caso de ausência do réu, autorizaria o processo por revelia. Todas as queixas são apresentadas ao magistrado por escrito. O magistrado marca o dia para a instrução e fixa em local público o texto da demanda. Os meios de prova admitidos são as leis, os contratos, os depoimentos de homens livres, as declarações de escravos obtidas pela tortura e o juramento das partes. Em todas as audiências eram feitas tentativas de conciliação entre as partes. As sessões dos tribunais tinham início bem cedo na manhã. As sessões julgavam vários processos privados e um processo público.

A sessão iniciava com uma prece e um sacrifício. Depois de anunciada a demanda, cabia a palavra ao autor e ao réu. As partes poderiam recorrer a oradores e amigos, para que os ajudassem durante o discurso, desde que este ofício não fosse pago. O tempo de fala é controlado. Nos processos privados, há direito de réplica para o autor e de tréplica para o réu. Até antes da abertura da urna, o autor pode desistir da ação ou fazer um acordo com o réu. Nos processos públicos, o autor que desistia da ação era condenado ao pagamento de multa de mil dracmas; nos processos privados, o autor perdia o direito de apresentar uma nova demanda. Durante 
os debates, os juízes desempenhavam o papel de jurados mudos e passivos. Após, a voz do arauto conclamava-os a votar sigilosamente.

Os sistemas de votos evoluíram do uso de conchas e de pedras para o uso de dois jetons de bronze, um inteiriço, para a absolvição, e outro furado, para a condenação, depositados, o que devia valer, numa urna de bronze e o outro numa urna de madeira.

Caso o resultado das urnas fosse a absolvição, terminava ali o processo. Nos processos públicos, os acusadores que não alcançassem um quinto dos votos ou desistissem da ação, eram condenados a uma multa e a uma atimia especial.

No caso de condenação, o direito grego admitia duas hipóteses: os processos com estimação de pena, determinada de antemão pelo decreto ou lei de encaminhamento ao tribunal, ou mesmo, mediante um acordo prévio entre as partes, e os processos sem estimação de pena. Nestes, o autor e o réu propunham, cada um ao tribunal, uma sanção: era a estimação (tímêsis) e a contraestimação (antitímêsis). Os juízes apenas poderiam escolher entre uma sanção e outra. Este sistema limitava o poder dos tribunais e explica a condenação de Sócrates.

No sistema penal ateniense, são as seguintes as penas corporais: condenação à morte, que incide sobre o homicídio premeditado, a traição e o sacrilégio, o exílio, que substitui a pena de morte, a atimia, a servidão penal e o encarceramento, e o castigo da flagelação, exclusivo aos escravos. As penas infamantes são: privação de sepultura, proibição a que mulheres adúlteras se ornamentem e penetrem nos templos, a imprecação e a inscrição do nome numa estela. As penas pecuniárias são o confisco total ou parcial de bens, as multas, e o pagamento de indenizações com juros por prejuízos. O julgamento, expressão da vontade popular, era irrevogável, soberano e perfeito, sendo rescindível em exceções como o julgamento à revelia, ações por falso testemunho e manobras fraudulentas.

\section{A COMÉDIA NA GRÉCIA CLÁSSICA}

Os gregos forjaram as instituições políticas ao mesmo tempo que teorizaram sobre sua própria prática. O legado grego que mais influenciou a civilização ocidental não foi o conjunto concreto de suas ações e os exemplos práticos de soluções políticas, mas a elaboração filosófica e teórica sobre a vida política da pólis. A criatividade grega não cansou de progredir e de meditar sobre a sua realidade e de compará-la com a de povos estrangeiros. A democracia foi apenas um dos regimes políticos analisados por Aristóteles. De maneira diversa da sociedade contemporânea, onde encontramos tautologicamente o consenso democrático como um dos pilares dos sistemas político e jurídico, os atenienses não estavam igualmente satisfeitos com o regime democrático ateniense. Não lhe faltaram críticas, principalmente de filósofos como Sócrates, Platão e Aristóteles, e de comediantes como Aristófanes. Para entender completamente a discordância desses personagens com a democracia ateniense, é preciso levar em conta as suas preocupações filosóficas e seus pressupostos, juntamente com as circunstâncias históricas peculiares de Atenas. Porém, a maior prova da democracia ateniense foi permitir a possibilidade de manifestações contrárias à ela própria. 
Para reconstituirmos a visão que os gregos possuíam de si mesmos, talvez uma das melhores formas seja analisar o teatro grego em uma de suas mais célebres manifestações, uma comédia de Aristófanes. Os dois maiores gêneros teatrais produzidos pelo teatro grego foram a tragédia e a comédia. Na definição de Aristóteles, tanto a tragédia quanto a comédia são imitações, a primeira de homens superiores, e a segunda, de homens inferiores, em sua parte ridícula (Aristóteles observa que a máscara cômica, sendo feia e disforme, não tem expressão de dor) (Poética, V, 1449a 32). Aristóteles concebia que a poesia, a tragédia e a comédia são todas imitações, e não escondeu seu desprezo por esta última.

Deixando de lado o preconceito aristotélico, a comédia de Aristófanes foi um veículo privilegiado de crítica social. Seuspeita-se que a peça Nas nuvens, de Aristófanes, cujo enredo satiriza Sócrates e seus discípulos, tenha influenciado o seu julgamento. A estrutura da comédia tradicional é dividida em seis partes (J.P. GOULD, Capítulo 7, O mundo intelectual. In: JONES, P. V. (Org.). O mundo de Atenas: uma introdução à cultura clássica ateniense. Trad. Ana Lia de Almeida Prado. São Paulo: Martins Fontes, 1997. p. 329):

"1 - o prólogo: os atores entram e, em uma seqüência típica de cenas que geralmente são irrelevantes e farsescas, apresentam a trama e a si mesmos e preparam-se para entrada do coro. 2 - A Párodos: a entrada muito esperada e, muitas vezes, muito espetacular do coro, ( por exemplo, um coro de aves em As Aves e de nuvens em As Nuvens). Normalmente, esse é o sinal de início da ação principal, a partir da qual se desenvolve um conflito que, com frequência, se dá entre os atores de um lado e o coro de outro.

3 - O agon (conflito): forma tradicional e estilizada de falas e canções alternadas que sempre incluem um pnigos ( um tour de force na forma de uma tirada que o ator devia dizer de maneira tão rápida que chegava a sentirse sufocado.

4 - A Parábasis: o coro vem diante do público e apresenta um conselho político que considera sério, freqüentemente nada tendo a ver com a peça.

5 - várias cenas farsescas e esquetes em que as consequiência do agon são resolvidas.

6 - O êxodos: a 'partida', em que os acontecimentos chegam a um clímax (incluindo, muitas vezes, comemorações ou um casamento) que anuncia o fim da disputa".

Nos trechos da peça que transcrevemos a seguir, intitulada As Vespas, o objeto da crítica são os tribunais do júri atenienses e o pagamento de três óbolos diários que todo cidadão que participava das sessões recebia. Esta peça foi estreada em $422 \mathrm{aC}$, tendo o primeiro ou o segundo lugar. Os principais personagens são Filoclêon, que significa amigo de Clêon, orador, general, político controvertido e seu filho Bdeliclêon (inimigo de Clêon). O primeiro é fanático pelas sessões do tribunal e o seu filho tenta curá-lo de sua mania judiciária, trancando o seu pai em sua própria casa. A seguir temos a fala de Xantias, um escravo de Filoclêon (ARISTÓFANES. As Vespas. Trad. do grego Mário da Gama Kury. Rio de Janeiro: Jorge Zahar Ed., 1996. p. 17-18):

\section{XANTIAS}

Dirigindo-se novamente aos espectadores.

Vocês estão perdendo tempo; nenhum de vocês vai esclarecer o caso. Se vocês estão ansiosos por saber, façam silêncio; vou dizer qual é mesmo a doença de meu senhor: é a paixão pelos tribunais. A paixão dele é julgar; ele fica desesperado se não consegue ocupar o primeiro banco dos juízes. À noite ele não goza um instante de sono. Se por acaso fecha os olhos, seu próprio espírito fica olhando para a 
clepsidra. A paixão dele pelo voto no tribunal é tão grande que faz ele acordar apertando três de seus dedos, como se oferecesse incenso aos deuses no dia da lua nova. Quando ele vê escrito nos muros "Demos encantador, filho de Pirilampo!", escreve ao lado: "Encantadora uma de votos!" Se seu galo cantava durante a noite ele dizia que algum acusado sem dúvida usava essa humilde ave para faze-lo acordar mais tarde do que era necessário. Logo depois do jantar ele pedia as sandálias, corria para o tribunal em plena noite e adormecia lá, colado a uma coluna como uma ostra à concha. Sua severidade o levava a tragar sobre as plaquetas do voto a linha da condenação, e ficava com os dedos cheios de cera. Com receio de não ter a pedrinha para o voto, ele tinha no jardim de sua casa um canteiro de pedrinhas, que renovava sem parar. Esta era a sua loucura. E as censuras deixavam o coroa excitadíssimo. Também fechamos o ferrolho da porta principal para impedi-lo de sair, pois esta "doença" deixava o filho desesperado. No começo este usa a doçura, lhe pede para não ficar todo o tempo com o manto de sair, e permanecer em casa. Depois de um banho no pai e purifica ele, mas tudo isto é inútil. Ele sujeita o pai aos exercícios sagrados dos Coribantes; o pai foge com o tambor e corre para o tribunal querendo julgar. Diante do fracasso dessas tentativas, ele leva o pai a Áigina para se deitar de noite no templo de Asclépio, mas quando amanhece o dia lá está o velho no recinto reservado aos juízes no tribunal. Fazemos o possível para impedi-lo de sair, mas ele escapa pelas calhas e pelos canos de águas das chuvas; onde aparecia um buraco, nos tapávamos e fechávamos imediatamente todas as saídas, mas ele punha paus nos muros e saltava de um lado para o outro como se fosse um gato. Afinal pusemos redes fechando todo o acesso ao jardim e ficávamos de guarda. O velho se chama Filoclêon; nenhum nome ficaria melhor nele. O nome do filho dele é Bdeliclêon; ele faz tudo para dominar o gênio fogoso do pai.
No diálogo a seguir, os componentes do coro (jurados como Filoclêon), chegam em frente à sua casa, fantasiados de vespas, antes do amanhecer, para levá-lo com eles ao Tribunal, e lutam com Xantias e Sosias, escravos de Filoclêon, tentando liberta-lo da prisão domiciliar a que o filho (Bdeliclêon) o sujeita. É de se notar a conotação que o termo tirania adquiriu nesta época, apogeu da democracia ateniense, visível na última fala de Bdeliclêon no trecho (Idem, ibidem, p. 36-37):

\section{BDELICLÊON}

Basta! Basta, Xantias! Enxote estas vespas daqui de casa!

\section{XANTIAS}

É o que estou fazendo.

\section{SOSIAS}

Eu também já estou dando porradas neles.

\section{Dirigindo-se a XANTIAS.}

E você, faça aí de seu lado uma fumaça espessa.

\section{XANTIAS}

Muito bem! Vocês pensam que vão se salvar? Então vocês não querem ir embora? Bastão neles!

\section{SOSIAS}

Você, Xantias, jogue no fogo este Aisquines filho de Selártio para fazer mais fumaça.

\section{XANTIAS.}

Eu sabia que íamos conseguir expulsar vocês daqui.

\section{BDELICLÊON}

Mas você não ia poder fazer este pessoal debandar com tanta facilidade se eles tivessem engolido versos de Filoclés. 


\section{CORO}

Não é para os pobres que a ditadura foi restabelecida aqui sem nós sabermos? Celerado! Correligionário do arrogante Aminias! Você espezinha as leis estabelecidas pela democracia, sem o menor pretexto nem palavras melosas que justifiquem o seu desrespeito?

\section{BDELICLÊON}

Não é possível conversarmos sem pancadaria e gritaria?

\section{CORO}

Conversar com você, inimigo do povo, partidário da monarquia e amigo de Brasidas, você, que ainda usa franjinhas de lã e deixa crescer a barba?

\section{BDELICLÊON}

De fato, eu agiria melhor se abandonasse logo meu pai em vez de suportar todos os dias borrascas como esta!

\section{CORIFEU}

Muito bem; você ainda não está no jardim nem saiu da rua, como diz o provérbio. O que você sofre hoje não é nada; você vai ver quando o promotor denunciar os seus crimes e intimar os seus cúmplices na conspiração.

\section{BDELICLÊON}

Em nome dos deuses! Vocês afinal vão embora? Se não forem, estou decidido a desancar vocês durante todo o dia.

\section{CORO}

Não e nunca, enquanto nos restar um sopro de vida!.Estamos percebendo claramente que vocês aspiram à tirania!

\section{BDELICLÊON}

Para nós tudo é tirania e conspiração; pouco me importa se as acusações são sérias ou infundadas. Durante cinqüenta anos estas palavras não tinham ferido os meus ouvidos; hoje elas são mais comuns que peixe salgado; elas reboam por todos os cantos da praça do mercado. Tanto faz alguém comprar peixe-agulha e desprezar o linguado, o vendedor do linguado diz logo: "a cozinha deste homem cheira horrivelmente a tirania”. Se outro pede pimenta para temperar as enchovas, o vendeiro olha de lado e.diz: "Você pede alho; será que o que você quer mesmo é a tirania? Você pensa que Atenas deve lhe fornecer os temperos?".

A seguir temos, na seqüência original da peça, um debate entre pai e filho, entre Filoclêon e Bdeliclêon, quanto aos méritos e defeitos do Júri em Atenas. O primeiro defende o sistema judiciário em função das vantagens pessoais que obtém em função do exercício do cargo, e o segundo o ataca, alegando que a maior quantia dos fundos arrecadados por Atenas são desviados pelos governantes e o pagamento diário de três óbolos pela presença nas sessões de julgamento é uma forma de obter a submissão dos juízes (Idem, ibidem, p. 40-45):

\section{BDELICLÊON}

Quero tomar nota de tudo que ele vai dizer, para não esquecer.

\section{FILOCLÊON}

E vocês, que iriam dizer se eu morresse?

\section{CORO}

A tropa de velhotes não serviria para mais nada. Seríamos ridicularizados nas ruas e chamados de anjos de procissão e de arquivos para processos. Você, então, Filoc1êon, que vai defender nossa soberania, mostre altivamente toda a sua eloqüência.

\section{FILOCLÊON}

Desde o comecinho vou provar que nosso poder não se curva diante de nenhuma soberania. Que criatura é mais feliz, mais afortunada que um juiz? Que vida é mais gostosa que a dele? Que animal é 
mais temível, principalmente na velhice? Mal me levanto da cama os homens mais importantes me escoltam até o tribunal; desde que apareço sou docemente paparicado por mãos que roubaram o dinheiro do tesouro da cidade; o culpado cai aos meus pés, dizendo com voz lamentosa: "Tenha piedade de mim, meu pai, pelos trambiques que pude praticar no exercício de funções públicas, ou no abastecimento do exército!" Pois ele não saberia nem que existo, se eu já não tivesse absolvido ele uma vez.

\section{BDELICLÊON}

Quanto aos suplicantes, tomei nota deles em minhas plaquetas.

\section{FILOCLÊON}

Aí eu me sento em meu lugar no tribunal, atordoado por súplicas que diminuem um pouco a minha severidade; e não faço nada do que prometo. De todos os lados se ouvem lamentos dos acusados. Que mesuras gentis se fazem diante do juiz! Uns deploram sua miséria e acrescentam males imaginários a seus males reais, para iguala-los aos meus; outros me contam histórias ou alguma piada de atores de comédias; outros dizem palavras espirituosas para me fazer rir e relaxar meu rigor. Se nada disso me sensibiliza, eles trazem seus filhos pelas mãos, meninos e meninas; eu ouço; eles inclinam a cabeça e começam a balir juntos, como se fossem carneiros. Depois o pai, trêmulo, suplica em nome dos filhos, como se eu fosse um deus, para eu absolvê-1o com pena deles: "Você gosta dos berrinhos de um cordeiro? Seja sensível à voz de um rapazinho" Se dou a impressão de gostar da "coisinha" das meninas, ele procura me comover com a voz da filha. Então o nosso humor se adoça um pouco. Isto não é reinar e estar acima das riquezas todas?

\section{BDELICLÊON}

Outro ponto que anoto: o desprezo pelas riquezas. Me diga agora: que vantagens você tira dessa prepotência que você tem a pretensão de exercer sobre a Hélade?

\section{FILOCLÊON}

Se se trata de verificar a idade dos meninos, temos o direito de vê-los nus. Se Ôiagro for citado judicialmente, ele não será absolvido antes de haver recitado diante de nós a mais bela tirada da Níobe. Um flautista ganha sua causa? Em sinal de reconhecimento ele toca uma marcha para nós quando saímos do tribunal. Se um pai moribundo indica no testamento o marido que destina à filha, única herdeira, deixamos com ele o mísero testamento e a conchinha que cobre o selo e damos a moça àquele cujas súplicas conseguem nos comover. E tudo isto sem dar satisfações a ninguém (privilégio que nenhum outro magistrado tem).

\section{BDELICLÊON}

Estas vantagens são preciosas, e eu felicito você por elas, mas cassar o testamento me parece injusto.

\section{FILOCLÊON}

Mas isto não é tudo. Quando o Senado e o povo estão divididos sobre algum assunto importante, um decreto manda os acusados comparecerem diante dos juízes. Vêem-se, então, Êatlo e também o frouxo Colacônimo jurarem que nunca trairão vocês e que lutarão pelo povo. Enfim, nenhum orador consegue fazer prevalecer sua opinião na assembléia se não declara que os tribunais teriam de fechar depois do julgamento de um caso. O próprio Clêon, com sua voz tonitruante, não nos morde; mas ele fica vigilante perto de nós e afasta as moscas. Você nunca fez nada comparável com o que seu pai fez. Teoro, digno rival de Eufêmio, pega a esponja na bacia para tirar a lama de nossas sandálias. Veja os benefícios de que você quer me privar, me arrancar! É isto que você chama de escravidão e servilismo?

\section{BDELICLÊON}

Fale tanto quanto você quiser; um dia você perceberá a inutilidade dessa maravilhosa prepotência; você terá de ser muito lavado depois de tanta sujeira! 


\section{FILOCLÊON}

Esqueci o melhor da história: quando entro em casa com meu salário, minha grana atrai mil carícias para mim; primeiro minha filha lava e perfuma os meus pés, e fica na ponta dos pés para me beijar, e me chamando pelos nomes mais carinhosos consegue tirar com sua língua os três óbolos de minha boca. Minha mulher, cheia de meiguice, me oferece uns bolos leves, sentando-se perto de mim e dizendo insistentemente: “Coma este! Prove aquele!” Tudo isso me deixa alegre; tudo isso me agrada muito; não tenho de olhar para você nem para o mordomo tentando saber quando ele ou você vão mandar servir o jantar, me maldizendo e resmungando, não é necessário lembrar que eles preparam um bolo ruim. E este salário me serve de proteção contra todos os males, e de armadura contra todos os projéteis; se você não quer servir o vinho, num instante o copeiro enche a taça e é só eu beber; o gluglu do vinho caindo na taça faz muito barulho e não me deixa ouvir seus gritos, meu filho. Isto não é uma verdadeira soberania, igual à de um Zeus? Falam de nós como do próprio Zeus. Se fazemos barulho em nosso tribunal, todos os presentes gritam: "Ah! Zeus! Que tempestade desaba sobre o tribunal!" Quando lanço meus raios os ricos e os mais emproados começam a me adorar e se borram de medo. Você mesmo, meu filho, tem muito medo de mim (sim, por Deméter!)'.

\section{BDLICLÊON}

Que eu morra agora mesmo se tenho medo de você!

\section{CORIFEU}

Nunca ouvi alguém defender uma causa com tanta habilidade e prudência

\section{FILOCLÊON}

Ele pensava que ia colher as uvas de uma parreira sem dono, mas já conhecia o meu talento.

\section{CORIFEU}

Como ele soube dizer tudo, sem esquecer coisa alguma! Eu sentia que estava crescendo enquanto ele falava. O encanto da eloqüência do velhote era tão grande que parecia que ele estava julgando nas ilhas dos Bem-aventurados!

\section{BDELICLÊON}

Como ele se babava de prazer e ficava em estado de beatitude!

\section{Dirigindo-se a FILOCLÊON.}

Vou fazer você sonhar hoje com chicotadas.

\section{CORIFEU}

\section{Dirigindo-se a BDELICLÊON.}

Você vai ter de pôr para funcionar todos os seus recursos se quiser ganhar a sua causa. É difícil me dobrar falando contra mim. Se você não tem nada de bom a dizer, procure já um moinho capaz de moer a minha cólera.

\section{BDELICLÊON}

De fato, curar uma doença crônica numa cidade como esta é uma tarefa difícil, ousada e superior às forças de um poeta cômico. Mas meu pai, filho de Cronos ...

\section{FILOCLÊON}

Pare de invocar o nome do pai! Se você não me provar agora mesmo que um juiz é um escravo, nada me impedirá de matar você, ainda que eu tenha de ser excluído da festa.dos Sacrifícios.

\section{BDELICLÊON}

Me ouça com um ar um pouco menos severo, pai. Faça pritneiro um cálculo, muito simples em seus dedos, e não com pedrinhas, de todos os tributos que as cidades nos pagam; conte também os impostos pessoais, os percentuais, as custas judiciárias, a parte do produto das minas, os direitos sobre os mercados e os portos, as taxas, o produto dos confiscos; a soma destas rendas sobe a quase dez mil talentos. Conte também os honorários anuais dos juízes, no valor de seis mil talentos, pois nunca houve tantos gastos deste tipo aqui; a soma de tudo isto é de cento e cinqüenta talentos para vocês. 


\section{FILOCLÊON}

Então não temos nem mesmo a décima parte das rendas públicas?

\section{BDELICLÊON}

Não

\section{FILOCLÊON}

Então para onde vai o resto?

\section{BDELICLÊON}

Para essa gente que não pára de gritar: "Nunca trairei o povo de Atenas! Lutarei sempre pelo povo!" E você, meu pai, seduzido por palavras como estas, se submete ao império dessa gente. Eles extorquem uma porção de talentos das cidades, fazendo ameaças a elas. Você se contenta com roer os restos do reinado deles. Os aliados, vendo todo o bando de vocês se contentar com uma sopa aguada e com a comida mais intragável, não fazem mais caso de você do que do voto de Cono. E aos demagogos eles dão pratos de peixe salgado, vinho, tapetes, queijo, mel, gergelim, almofadas, jarros bonitos, roupas caríssimas, coroas, colares, copas, enfim, as riquezas companheiras da boa vida. E a você, nenhum daqueles em quem você diz que manda, depois de tantas canseiras em terra e no mar, dá nem mesmo uma.cabeça de alho para temperar uns peixinhos de nada.

\section{FILOCLÊON}

Isto é verdade; tive de mandar buscar três dentes de alho na quitanda de Eucarides. Mas afinal você não me prova esta suposta servidão.

\section{BDELICLÊON}

E não é uma verdadeira servidão ver todos esses intrigantes que exercem as magistraturas e seus aduladores presenteados com salários de marajás? Enquanto isto, você se contenta com os três óbolos que lhe pagam e que você ganhou em mil combates em terra e no ar e no cerco de cidades. Mas o que me deixa ainda mais revoltado é que você é forçado a ir à assembléia por ordens de outros, enquanto um fedelho debochado - o filho de Caireas (o das pernas tortas) -, de andar provocante e cheio de frescura, convida você para vir julgar de manhã cedinho e na hora marcada, pois quem se apresentar depois do sinal não porá as mãos nos três óbolos. Mas ele recebe um bom dinheiro, na qualidade de promotor público, por mais tarde que chegue. Se algum acusado dá qualquer presente a ele, o malandro divide o presente com um de seus coleguinhas; se os dois combinam arranjar uma negociata, passam a maracutaia das mãos de um para o outro como dois malabaristas com batatas quentes nas mãos; enquanto isto você, com a boca escancarada, fica olhando para o tesoureiro do tribunal, sem perceber a manobra.

\section{FILOCLÊON}

O quê? É assim que eles me tratam? Essa não! Que é mesmo que você está dizendo? Você está pondo o meu espírito de cabeça para baixo! Isto me faz pensar muito. Já não sei onde estou!

\section{BDELICLÊON}

Então ouça: você poderia ser tão rico quanto todos os outros colegas seus; mas esses eternos aduladores do povo lhe tiram os meios. Você reina sobre uma porção de cidades, desde o mar Negro até a Sardenha, e sua única satisfação é esse salário miserável; e eles ainda lhe pagam avarentamente e gota a gota, como o óleo na mecha de um lampião; na realidade eles querem que você seja pobre, e vou lhe dizer a razão disto: é porque você conhece a mão que te alimenta, e ao menor sinal você se lança sobre o inimigo que ela escolhe para ser atacado por você. Garantir a subsistência do povo seria coisa fácil, se você quisesse. Mil cidades nos pagam tributos. Se se impuser a cada uma delas que sustente vinte cidadãos, vinte mil homens viverão uma vida de delícias. Eles terão todas as lebres que quiserem, coroas, o primeiro leite das mulheres depois do parto, enfim, todas as coisas boas que nossa pátria e os vencedores da batalha de Maratona merecem. 
Longe disto, agora vocês seguem aquele que paga o salário, como os colhedores de azeitonas. (Idem, ibidem, p. 40-45).

No meio da peça cômica temos o ponto sério da comédia, a parábasis, um discurso em forma de conselho político, proclamado pelo coro ao auditório, sem um relação direta com a seqüência do enredo. Neste caso, Aristófanes ataca os juízes que julgam sem ter merecido o cargo, sem ter lutado na defesa de Atenas contra os seus invasores, e explica o sentido simbólico das vespas na peça (idem, ibidem, p. 64-66):

\section{PARÁBASE}

Vamos até onde a alegria nos chama. Vocês, espectadores incontáveis, não deixem cair por terra as sábias palavras que vou pronunciar: isto seria de esperar de ignorantes, e não de vocês. E agora, cidadãos, prestem atenção ao que vou dizer, se vocês gostam de uma linguagem sincera. Neste momento o poeta deseja dirigir algumas censuras a vocês. Ele acha que tem motivos para se queixar de vocês, ele, que foi muitas vezes o primeiro a ser agradável a vocês.

Primeiro sem dizer o seu verdadeiro nome, escrevendo comédias sob o pseudônimo de outros poetas. Naquele tempo ele imitava a linguagem profética de Euriclés, e lhes falava com as entranhas. Depois, enfrentando diretamente o perigo, ele tomou as rédeas nas mãos e guiou sua própria Musa em sua carreira. Cercado de glória e honrarias, como nenhum outro jamais havia recebido, ele não imaginou que havia atingido o Ápice da perfeição, e não passou a sentir maior orgulho por isso; jamais ele percorreu os ginásios atléticos para corromper a juventude neles; se algum amante avançava para queixar-se a ele de que a comédia visava o alvo de seus amores, ele jamais se dava por vencido diante do assédio, com a louvável intenção de não atribuir às Musas que o inspiravam o papel de alcoviteiras.
Na primeira vez que ele apareceu com seu próprio nome no teatro, não foram homens que ele teve de enfrentar: ele teve de se armar da força de Heraclés contra monstros terríveis; ele ousou desde o princípio atacar esse Cérbero de dentes afiados, cujos olhares aterradores lançavam chamas como as de Cina, e cuja fronte era lambida pelas línguas pervertidas de cem aduladores, reunidos em círculo em volta dele; ele tinha a voz de uma torrente avassaladora, o fedor de uma foca, as coxas de uma Lamia, e o ânus de um camelo; diante da visão desse monstro, o terror não lhe arrancou presentes para acalmá-lo. Apesar de tudo isso, até hoje o autor luta por vocês.

No ano passado ele atacou também outros flagelos, outros vampiros, que durante a noite estrangulavam os próprios pais e sufocavam os avós; gozando da intimidade de cidadãos inofensivos, eles os perseguiam e os soterravam com processos judiciais, acusações e chicanas; também podia-se vê-los correr em grande número para implorar a proteção do polemarca. Vocês tinham achado um defensor, um salvador, mas o abandonaram no ano passado, enquanto ele semeava seus pensamentos mais novos que não tinham sido bem compreendidos. Entretanto, em meio às libações ele toma Diôniso por testemunha de que jamais foram ouvidos melhores versos cômicos. É uma vergonha para vocês o fato de não terem percebido imediatamente o mérito do poeta; mas o poeta não é menos estimado pelos sábios por haver sido espoliado da vitória, embora fosse melhor que seus rivais. No futuro, maravilhosos atenienses, amem e honrem os poetas que buscam idéias novas e invenções; preservem seus pensamentos, esforcem-se por conservá-los como preciosidades em seus cofres; se vocês tiverem este cuidado, suas roupas exalarão durante o ano inteiro um perfume de... esperteza...

Ai de nós, antigamente tão hábeis na dança, tão valentes nos combates e ainda mais valentes na virilidade! Estes belos dias já passaram. Agora a brancura de nossos cabelos iguala a dos cisnes, 
mas o que ainda resta reencontrará a pujança da mocidade. Nossa maturidade vale mais que os adornos, os trejeitos efeminados e a devassidão de muita gente jovem.

Se algum de vocês, espectadores, vendo as nossas roupas admirar-se de nos ver com a aparência de uma vespa e armados com este ferrão, explicaremos as coisas e dissiparemos a ignorância de vocês. Esta gente armada de ferrão é gente da Ática, única autóctone e única nobre; raça cheia de coragem e que defendeu muitas vezes esta cidade em combates, na 6 poca em que os persas vieram arrasar a nossa terra natal e cobri-la de fogo e fumaça, com o propósito de destruir nossas colméias. Rapidamente cada am de nós empunhou sua lança e seu escudo, e marchou contra o inimigo; combatemos em Maratona e em Salamina impelidos pela cólera, homem contra homem, com os lábios cerrados de fúria; a quantidade de lanças arremessadas impedia a visão do céu. Afinal pusemos em fuga os atacantes quando já anoitecia, com a ajuda dos deuses. Antes da batalha uma coruja havia passado por cima de nosso exército; perseguimos os invasores atacando seus flancos com nossos ferrões. E assim, até hoje os bárbaros não conheceram nada de mais terrível que as vespas áticas. A coragem delas foi inacreditável; nenhum temor as detinha; a bordo de nossas naus acabamos de destruir nossos inimigos. Naquele tempo pensávamos não em fazer discursos artisticamente elaborados, nem em caluniar uns aos outros, mas em nos tomarmos bons remadores. Conquistamos numerosas cidades dos persas. É, então, principalmente ao nosso próprio valor que devemos os tributos que os jovens dilapidam.

Examinando cuidadosamente, vocês encontrarão em nós uma semelhança total com as vespas, tanto pelo caráter como pela maneira de viver. Primeiro, nenhum bicho é mais irascível e mais terrível quando o irritam; depois, todas as nossas ocupações lembram as das vespas. Formamos como elas diversos enxames que se dispersam em colméias diferentes; uns vão julgar junto ao arconte, outros junto aos Onze, outros no Odeon; alguns deles, espremidos contra as muralhas da cidade, com a cabeça baixa, apenas mexendo-se, como se fossem larvas em seus alvéolos. Nossa atividade proporciona abundantemente a satisfação de todas as necessidades da vida (para isto, basta picar com nossos aguilhões). Mas temos entre nós zangões indolentes, desprovidos dessa arma, que, sem participar de nossas fadigas, devoram os frutos delas. Para nós é verdadeiramente intolerável ver nossos salários roubados por quem nunca entra em combate, e que jamais faz calos manejando a lança ou o remo para defender a pátria. Em uma palavra, nossa opinião é que, no futuro, quem não tiver ferrão não porá a mão nos três óbolos.

No trecho abaixo, Filoclêon, depois de embriagar-se totalmente em um jantar, onde foi levado por seu filho, acaba provocando conflitos com outros convidados, insultando-os e agredindo-os, como uma padeira e um cidadão que foi ferido por ele. A situação reflete o fato de que qualquer cidadão ateniense poderia levar a julgamento outro cidadão. $\mathrm{O}$ processo era um direito de todos. Para a instrução da causa, geralmente o autor levava suas testemunhas. Aristófanes satiriza o depoimento combinado entre autor e testemunha, ao mesmo tempo que transforma seu principal personagem, Filoclêon, ridicularizado por sua postura nada social, em réu e não mais em Juiz (idem, ibidem, p. 79-81):

Entra uma vendedora de pão com o cesto vazio e acompanhada por CAIREFON como testemunha.

\section{PADEIRA}

Dirigindo-se a CAIREFON.

Em nome dos deuses, venha cá me socorrer!

Apontando para FILOCLÊON. 
Este homem me arruinou! Ele me afastou com sua tocha e me fez derrubar dez pães de um óbolo e outros quatro ainda mais caros!

\section{BDELICLÊON}

Dirigindo-se a FILOCLÊON.

Você vê o que fez? Sua falta de vergonha vai provocar questões e processos judiciais.

\section{FILOCLÊON.}

De jeito nenhum! Pequenos acertos de contas resolvem as maiores questões. Sei perfeitamente como me entender com ela.

\section{PADEIRA}

Pelas duas deusas, você estragou minha mercadoria mas vai me pagar! Eu, Mórtia, filha de Ancílion e de Dóstrata, não vou deixar que abusem de mim sem levar o troco!

\section{FILOCLÊON}

Escute, menininha, vou lhe contar uma história muito bonita.

\section{PADEIRA}

Não quero ouvir história nenhuma!

\section{FILOCLÊON}

Um dia Esopo, voltando do jantar, viu-se perseguido por uma cadela indecorosa e bêbeda que não parava de latir."Cadela", disse ele, "você faria melhor negócio trocando sua má língua por um pedaço de pão".

\section{PADEIRA}

Você está me gozando? Muito bem! Seja você quem for vou levar você à presença das autoridades para obter reparação pelo prejuízo que me causou. Cairefon, que está aqui, será minha testemunha.

\section{FILOCLÊON}

Ao menos me ouça, moça, pois posso ter alguma coisa a lhe dizer. Laso e Simonides um dia disputavam para saber qual dos dois era mais talentoso, e Laso então disse: "Pouco me importa!"

\section{PADEIRA}

De fato! É assim mesmo!

\section{FILOCLÊON}

\section{Dirigindo-se a CAIREFON.}

E você, Cairefon, vai então ser testemunha de uma mulher de cara pálida, de Ino precipitando-se de um rochedo aos pés de... Eurípedes?

Saem a PADEIRA e CAIREFON. Entra um ACUSADOR muito ferido trazendo uma testemunha.

\section{BDELICLÊON}

\section{Dirigindo-se a FILOCLÊON}

Vem chegando outra pessoa que parece estar aqui também para processar você. Ele está trazendo uma testemunha.

\section{ACUSADOR}

Ai! Como sou infeliz! Acuso você de me ultrajar, velhote!

\section{BDELICLÊON}

De ultrajar você? Em nome dos deuses eu suplico: não acuse ele! Eu lhe pago em nome dele a indenização que você exigir, e você ainda terá todo o meu reconhecimento.

\section{FILOCLÊON}

Eu mesmo quero me reconciliar com ele; reconheço que bati nele e o apedrejei.

\section{Dirigindo-se ao ACUSADOR.}

Venha cá; você me deixa estipular, eu mesmo, a reparação que lhe devo, ou você prefere dizer quanto é?

\section{ACUSADOR}

Diga você, pois detesto os processos e discussões na Justiça. 


\section{FILOCLÊON}

Um sibarita caiu de seu carro e ficou gravemente ferido na cabeça; ele não era um bom escudeiro; um de seus amigos chegou e lhe disse: "Que cada um faça aquilo em que é competente!" Da mesma forma, o que você tem a fazer é ir procurar Pítalo, o médico.

\section{BDELICLÊON}

Você continua o mesmo! ...

\section{ACUSADOR}

Dirigindo-se à sua testemunha.

Lembre-se bem da resposta que você deve dar.

No último trecho apresentado, desenhase a parte final da peça, que se resume na tentativa de Bdeliclêon de reeducar o pai para a vida social, levando-o a jantares, porém, o resultado é desastroso, como visto, pois Filoclêon embriaga-se e insulta outros convidados, e afinal acaba pondo-se à frente dos componentes do coro para dançar indecentemente. A peça de Aristófanes termina com o coro dançando. Esta é a última frase: "Mas se estas danças agradam a vocês, deixem que nós saiamos, dançando cada vez mais depressa, pois até hoje ninguém mandou sair do palco um coro de comédia!" (id., ib., p. 87). Deste modo, a obra de Aristófanes é uma das mais ricas fontes para se recuperar os detalhes do cotidiano da vida ateniense, e principalmente, para reconstruir, pela via da imitação e da comédia, a imagem que os atenienses possuíam de si mesmos.

\section{REFERÊNCIAS}

ARISTÓFANES. As Vespas. Trad. do grego Mário da Gama Kury. Rio de Janeiro: Jorge Zahar Ed., 1996.

ARISTÓTELES. Poética. Col. Pensadores. Trad. Eudoro de Souza. São Paulo: Nova Cultural, 1987.

GLOTZ, G. A Cidade Grega. Trad. Henrique de A. Mesquita e Roberto C. de Lacerda. 2 ed. Rio de Janeiro: Bertrand Brasil, 1988.

JONES, Peter V. (Org.). O mundo de Atenas: uma introdução à cultura clássica ateniense. Trad. Ana Lia de Almeida Prado. São Paulo: Martins Fontes, 1997. 